\title{
HRM and Performance - The Role of Talent Management as a Transmission \\ Mechanism in an Emerging Market Context
}

\author{
Alison J. Glaister ${ }^{a}$, Gaye Karacay Aydin ${ }^{\text {, }}$, Mehmet Demirbag ${ }^{\text {c\# }}$, Ekrem Tatoglu ${ }^{\text {d }}$
}

${ }^{a}$ Lecturer in Strategic HRM, The York Management School, University of York, Freboys Lane, Heslington, York, YO10 5GD, United Kingdom. E-mail: alison.glaister@york.ac.uk

${ }^{\mathrm{b}}$ Assistant Professor of Management and Organization, Faculty of Management, Istanbul Technical University, Macka, Istanbul, 34367, Turkey. Email: karacayaydin@itu.edu.tr

${ }^{c}$ Professor of International Business, Essex Business School, University of Essex, Southend Campus, Elmer, Southend-On-Sea, SS1 1LW, United Kingdom. E-mail: mdemirc@essex.ac.uk

${ }^{\mathrm{d}}$ Professor of International Business, School of Business, Ibn Haldun University, Basaksehir, Istanbul, 34494, Turkey. Email: ekrem.tatoglu@ihu.edu.tr

${ }^{\#}$ Corresponding author:

Professor Mehmet Demirbag, Chair in International Business,

Deputy Dean and Professor of International Business, University of Essex, Essex Business School, Southend Campus,

Elmer Approach,

Southend-on-Sea,

SS1 1LW

United Kingdom

E-mail: mdemirc@essex.ac.uk 


\title{
HRM and Performance - The Role of Talent Management as a Transmission Mechanism in an Emerging Market Context
}

\begin{abstract}
This paper examines the link between HRM practices, talent management and firm performance, and examines the role of HRM/business strategy alignment in an emerging market context. Through survey evidence gathered from 198 respondent firms, this study shows that talent management, when focused on a series of practices aimed at developing workforce networks and social capital, is a key transmission mechanism mediating the relationship between HRM and firm performance. HRM strategy and business strategy alignment increases these performance impacts but is not an essential component in the HRM-TMperformance link.
\end{abstract}

Keywords: Talent management, firm performance, dynamic capabilities, emerging markets. 


\section{Introduction}

The employment context is changing as organisations face demographic and economic pressures, the increasing mobility of human capital through globalisation and a greater shift towards knowledge based economies (Beechler and Woodward, 2009, Guthridge et al., 2008). Organisational success now depends on sustaining business through people (Boudreau and Ramstad, 2005) and as globalization intensifies, so too does the need for talent. A premium is placed on the process of talent management (TM) as organisations position themselves as employers of choice, developing strong employer brands and a defined value proposition through their TM systems (Martin and Cerdin, 2014, Schuler, 2015, Sparrow and Makram, 2015). TM involves sourcing the right talent, developing a flexible talent base and meeting the demands of different psychological contracts, marshalling effective strategy and managing risk (Sparrow et al., 2011, Sparrow et al., 2014). The issues of managing talent are universal but are more acute in emerging market economies (Pelster et al., 2013, Doh et al., 2014) where talent shortages highlight a pressing need for organisations to adopt strategic approaches to TM. Yet many organisations still consider talent a short term concern (Guthridge et al., 2008) and scholarly research suggests a disconnect between TM and organisational strategy (Chadee and Raman, 2012, Al Ariss et al., 2014).

Scholarly interest in TM is increasing (Meyers and van Woerkom, 2014, Nijs et al., 2014, Tatoglu et al., 2016). Despite this, only one third of scholarly output is empirical in nature (Thunnissen et al., 2013) and research is lagging behind practice (Dries, 2013). More needs to be done to understand the alignment between human resource management (HRM), TM and firm performance. This phenomenon is best studied in a context where TM is likely to have an impact, specifically in an emerging market, in which the linkages, if they exist, are more likely to be detected because of the heightened relevance of TM fuelled by growing industrial capacity, consumer markets and earning potential (Doh et al., 2014, Harvey and Groutsis, 2015).

This paper examines the link between HRM practices, TM and firm performance and the role of HRM/business strategy alignment. The contribution of this paper is threefold: First, it contributes to an understanding of how TM operates as a transmission mechanism by 
combining the resource based view (RBV) with dynamic capabilities. Research examining the relationship between HRM, TM and firm performance has been largely absent in the literature. Second, to the best of our knowledge, it is the first to test the centrality of the HRM function to the HRM-TM-performance link. Third, it identifies the TM practices that impact performance in an emerging market context.

The paper is structured as follows: the relationship between HRM and firm performance is examined using $\mathrm{RBV}$ to explain how resource characteristics create advantage. Dynamic capabilities are introduced to explain how TM operates as a transmission mechanism, mediating the HRM-performance link. The role of the HRM function in HRM-business strategy alignment is examined alongside its struggle for legitimacy within the organisation. Each of these areas frames a set of hypotheses that are presented throughout. An examination of the research methods is then followed by a discussion and conclusion. A series of implications for practitioners, study limitations and possible avenues for further research are presented.

\section{HRM and TM as a Transmission Mechanism}

HRM focuses on each of an organisation's employees, whereas TM focuses on an exclusive set of pools, people, positions or practices that add the most value to the firm (Sparrow et al., 2014, Tarique and Schuler, 2014). TM considers the contextual value and differential contributions of key actors within the organisation (De Vos and Dries, 2013, Glaister et al., 2014, Linden and Teece, 2014) and develops "an advanced" and "sophisticated" set of supporting HRM policies and practices (Sparrow et al., 2014:51) to sustain maximum value. As such, TM is a key transmission mechanism (Chowhan, 2016) through which HRM practices interact to affect organisational performance.

The high performance work system (HPWS) consists of various bundles of HRM practices and much of the research in this area suggests that these systems contribute positively to organisational performance (Boselie et al., 2005). There is little agreement on what constitutes a definable bundle, but these can be disaggregated into skill enhancing (training) motivation enhancing (rewards) and opportunity enhancing practices (work design) 
(Lepak et al., 2006, Jiang et al., 2012, Chuang et al., 2016, Demirbag et al., 2016). This study uses the HRM practices employed in Tatoglu et al.'s (2016) study of an emerging market context and includes training and development, recruitment and selection, performance appraisal and workforce planning. Such bundles do not work in isolation but are part of a synergistic system combining internally while flexing to the external environment (Foss et al., 2015). The relationship between HRM and performance is explained through RBV (Wright et al., 2003, Wright et al., 2005), where organisations seek to maximise their internal resources through developing valuable, rare, inimitable and non-substitutable resources that are both socially complex and causally ambiguous (Barney, 1991, Barney and Wright, 1998). These characteristics depend upon management systems that are capable of exploiting value, but the HRM practices themselves are not the "direct" source of competitive advantage (Fu et al., 2015:2). Causality is problematic and the mechanisms through which HRM impacts performance are varied (Wright et al., 2005, Keller and Cappelli, 2014). The relationship between HRM and performance operates through a range of motivation related and human capital variables (Datta et al., 2005, Mellahi et al., 2013, Sahadev and Demirbag, 2011). These variables include the creation of a suitable climate (Lepak et al., 2006, Heffernan et al., 2016, Lin et al., 2016), the development of similar cognitive maps (Bowen and Ostroff, 2004, Ostroff and Bowen, 2016), the level of human capital (Snell and Dean, 1992, McMahan et al., 1999), employee attitudes and behaviours (Takeuchi et al., 2007, Shantz et al., 2016), each resulting in the potential for greater commitment (Gong et al., 2009), lower turnover (Wright et al., 2005), higher productivity and quality (MacDuffie, 1995) and better financial performance (Huselid, 1995).

Thus, for resources to have any performance advantage, they need to be managed effectively to create value - hence organisations need to develop dynamic capabilities that alter the resource base and promote change (Helfat et al., 2009). TM is a dynamic capability through which firms sense, seize and change their skills, resources and competencies (Linden and Teece, 2014). According to Ambrosini and Bowman (2009), dynamic capabilities are focused on the future and develop the most adequate resource base - their value is derived from their outputs. A bedrock of HRM practices, applied to the whole workforce consist 
primarily of ordinary or zero-order capabilities (Winter, 2003, Fainshmidt et al., 2016). These foundational capabilities merely enable the organisation to function on day-to-day basis (Helfat and Winter, 2011). However, they provide a stable platform on which to develop dynamic capabilities, which then act as transmission mechanisms improving ordinary capabilities and building a new sustainable resource base (Ambrosini and Bowman, 2009, Schilke, 2014, Teece, 2014). Thus, TM can be viewed as a transmission mechanism that enables organisations to constantly change (Rindova and Kotha, 2001). Indeed, Fainshmidt et al. (2016) and Weerawardena et al. (2007) suggest that dynamic capabilities in emerging markets yield superior benefits as they tend to be rare and can confer more value in turbulent economic conditions. This leads to the following research hypothesis:

Hypothesis 1: A foundation of HRM practices (that includes training and development, recruitment and selection, performance appraisal and workforce planning) is positively related to TM practices.

Measures of firm performance in HRM research have been contentious and varied and studies have measured a range of financial, organisational and HRM-related outcomes. These have included sales and profit per employee (Guest et al., 2003, Kim and Ployhart, 2014), innovation, labour turnover and social climate (Ait Razouk, 2011, Batt, 2002, Sheehan, 2014), return on assets and sales growth (Snell and Youndt, 1995), Tobins Q and firm survival (Welbourne and Andrews, 1996), productivity, shrinkage and machine efficiency (Wright et al., 2005, Youndt et al., 1996), as well as a range of perceptual and attitudinal measures including job satisfaction, commitment and trust in management, stress levels and work intensification (Hoque, 1999, Ramsay et al., 2000, Tsui et al., 1997, Whitener, 1990). This range of subjective and objective measures increase the difficulties of locating HRM/performance research within a theoretical framework (Boselie et al., 2005) but despite the diverse nature of these outcomes and the range of methodological issues inherent within the area of research, Paauwe et al. (2013) conclude that there is indeed a positive association 
between HRM and varied measures of performance. This study uses a subjective assessment of firm performance in relation to other firms in the same industry over the past three years.

By viewing TM as a dynamic capability, it is possible to begin to explain how TM mediates the HRM-performance link and alters the firm's resource base specifically through the way in which TM develops social capital - promoting cooperation and knowledge sharing which impacts collaboration across the value chain (Anand et al., 2007, Gardner et al., 2012). Researching top management teams, Collins and Clark (2003) suggest that networks impact performance through social capital and that HRM practices are correlated with the size and strength of network ties. Such ties break existing mental models, reduce perceptions of environmental complexity and increase information access to improve decision making (Peng and Luo, 2000). Social capital is central to sustainably leveraging resources, increasing the absorptive capacity of the organisation and protecting knowledge investment (Florin et al., 2003, Youndt and Snell, 2004, Soo et al., 2016). It creates greater cohesion and trust and a supportive organisational culture (Adler and Kwon, 2002). Through an appreciation of TM systems that develop social capital, it is possible to understand the caution against the individual transfer of talented employees (Groysberg et al., 2006, Groysberg, 2012) and the centrality that TM has in establishing value congruence (Mellahi and Collings, 2010, Huang and Tansley, 2012).

The TM practices adopted in this study include inter alia special tasks to stimulate learning, project teams, networking, project working, international assignments, international project teams, internal and external secondment, job rotation, coaching and mentoring. Each are opportunity enhancing practices, vital in empowering and motivating employees and increasing network intimacy (Youndt and Snell, 2004, Lepak et al., 2006, Jiang et al., 2012). These practices foster collaboration and team work and provide a stimulating work environment that encourages knowledge sharing and enhances the intensity of social interaction (Collins and Smith, 2006, Kaše et al., 2009, Chuang et al., 2016, Soo et al., 2016). They are a feature of a specific horizontal work design that can promote network flexibility and adaptability across different units (Mäkelä and Brewster, 2009, Kaše et al., 2009). TM that incorporates these practices enables changes to be made to the composition of the 
network. Thus, we contend that social capital enhancing TM practices are necessary and explain the relationship between HRM and firm performance leading to the following hypotheses:

Hypothesis 2: TM that focuses on social capital building practices is positively related to firm performance.

Hypothesis 3: TM that focuses on social capital building practices mediates the relationship between HRM and firm performance.

Scholars attest to the significance of the alignment between HRM and firm's strategy (Martell and Carroll, 1995; Rose and Kumar, 2006; Lepak et al., 2007) and firms are urged to establish a clear link between these and their TM strategies (Garavan, 2012, Tarique and Schuler, 2014, Schuler, 2015). In aligning business, HRM and TM strategies firms are more likely to achieve employee behaviours and outcomes commensurate with strategic success (Jiang et al., 2013), signalling the overall importance of TM within the organisation (Garrow and Hirsh, 2008, Garavan, 2012, Minbaeva and Collings, 2013). Indeed, business strategy and strategic implementation moderates the relationship between HRM and performance (Michie and Sheehan, 2005, Takeuchi, 2009, Peña and Villasalero, 2010), therefore highlighting the role of organisational capital - the databases, structures, systems and culture of the organisation - each "central in developing a firm's strategic capability" (Kang and Snell, 2009, Fu et al., 2015:14). The HRM function forms a central part of this system in designing, implementing, reviewing and institutionalising the HRM practices that form a bedrock and those that constitute TM (Youndt and Snell, 2004, Soo et al., 2016). They ensure consistent messages that improve the effectiveness of communication and ultimately strengthen the organisation's culture (Connelly et al., 2011). This consistency suggests that HRM is part of a cohesive and structured work environment. Lockett et al. (2009) posit that managers fail to understand the potential of the resources at their disposal, therefore 
emphasising the centrality of HRM expertise and their role in resource optimisation to further the strategic goals of the organisation (Jeong and Choi, 2015).

The involvement of the HRM function is viewed as a critical opportunity to contribute to an organisation's success, aligning HRM and business strategy to develop a corresponding set of TM practices and metrics (Minbaeva and Collings, 2013, Schuler, 2015). Thus, it is assumed that the HRM function is considered a partner to the business (Lawler and Boudreau, 2009, Tarique and Schuler, 2014) and is capable of 'managing' organisational cultures and supplying leadership and technical talent across the organisation (Tansley and Tietze, 2013, Garavan, 2012). Powerful HRM functions (in this study, variables that test HRM strategy-business strategy alignment) are those that have board level representation, form part of the top team and are involved in the strategic decision making of the organisation and are taken seriously (Lawler III, 2009, Sheehan et al., 2014, Gooderham et al., 2015). Yet, TM is viewed as the remit of the senior management team (Fernandez-Araoz et al., 2011) and HRM as a function has often struggled with its image and is often excluded from decision making, playing only a secondary role in cultural integration (Lawler and Mohrman, 2003, Björkman and Soderberg, 2006). It is hampered by the increasing fragmentation of HRM responsibilities, eroding stakeholder perceptions of their professionalism, status, credibility and knowledge (Caldwell, 2003). Indeed, there is doubt as to whether TM requires an integrated HRM function - leaders question the ability of the HRM function to seize the strategic centrality of TM and the HRM function questions its own ability to tackle TM challenges (Guthridge et al., 2008, Schuler et al., 2011, Tansley and Tietze, 2013). Instead, the process itself tends to be owned by line managers (Garrow and Hirsh, 2008), but more importantly, within the emerging market context there is doubt as to whether HRM as a function is sufficiently developed enough to engage in strategic level discussions on TM (Vaiman and Holden, 2011).

The influence of HRM and its systems may become obsolete in the presence of strong and empowering leadership (Chuang et al., 2016). Thus, the contested nature of the HRM function and the propensity for senior managers to bypass the HRM function suggests that HRM strategy and business strategy alignment, i.e. the extent to which HRM is taken 
seriously, forms part of the top team, is at the forefront of shaping business strategy, may not be a necessary condition for the link between HRM and TM practice and subsequent performance impacts. However, as the expertise of the HRM function is required, we suggest a moderating role for HRM strategy and business strategy alignment. This leads to the following hypotheses:

Hypothesis 4. HRM strategy and business strategy alignment moderates the relationship between HRM practices and TM practices.

Hypothesis 5. HRM strategy and business strategy alignment moderates the relationship between TM practices and firm performance.

Our conceptual model along with hypothesised relationships is shown in Figure 1.

\section{[Figure 1]}

\section{Methodology}

\subsection{Sample and Data Collection}

The sampling frame for firms in Turkey was drawn from the website of TOBB (The Union of Chambers of Commerce, Industry, Maritime Trade and Commodity Exchanges of Turkey, available at http://www.tobb.org.tr), which provides an industrial database containing over 40,000 firms. Within this sample frame small companies of fewer than 50 employees were excluded. This did not undermine the study as these companies are likely to be managed entrepreneurially with no recognizable HRM system. Through a random sampling selection procedure, a total of 800 firms was generated and constituted the sampling frame for the study.

A questionnaire, originally developed in English, was translated into Turkish and then re-translated into English by a second party to ensure accuracy in translation. This process of 'back translation' is useful in identifying misinterpretations and misunderstandings. To ensure 
the reliability of the translation, two bilingual translators were used in tandem to compare the back translated English and Turkish versions of the questionnaire and make any necessary changes. A Turkish version of the questionnaire and a covering letter were posted to the general manager of each subsidiary and indigenous firm along with a cover letter requesting that the general manager, or his/her senior executive in charge of HRM should complete it. After one reminder, a total of 211 questionnaires were returned, of which 198 were usable (an effective response rate of $24.75 \%$ ). The response rate was satisfactory, given the nature of the questionnaire and the type of potential respondent.

A test for non-response bias for the mail survey for each group of sample firms was conducted by comparing the first wave of survey responses to the last wave of survey responses (Armstrong and Overton, 1977). Nearly 50\% of the surveys were randomly selected for each of the first and last waves of questionnaires received, and t-tests were performed on the scores across groups. The test results indicated no significant difference in the responses between early and late respondents $(p>0.1)$ for any of the variables used in this study. For each sample, chi-square tests were also used to compare the respondent firms with nonrespondent firms across the main characteristics of the sample such as industry type, firm size and geographical location, and again showed no systematic relationships ( $p>0.1)$. Hence, no response bias was evident.

The characteristics of the respondent firms are summarized in Table 1.

\section{[Table 1]}

\subsection{Measurement of Variables}

The measures used to capture data for the empirical analyses were drawn from formerly implemented questionnaires used earlier by Lewis (2009) the Chartered Institute of Personnel and Development (CIPD) (2012) and the CRANET survey (Cranfield University, 2003).

Firm performance was treated as the dependent variable and was measured using a subjective assessment of firm performance in relation to other firms in the same industry over the past three years. Relying on five-point scales ( $1=$ "a lot below average" to $5=$ "a lot better 
than average"), our performance construct is composed of two items measuring firm's profit growth and profit margin. Wall et al. (2004) confirm that objective and subjective measures of company financial performance were positively correlated. Subjective measures of firm performance have been used extensively in empirical studies by several researchers (Glaister and Buckley, 1999, Collings et al., 2010, Demirbag et al., 2014).

The implementation level of HRM practices was captured by a total of $10 \mathrm{HRM}$ practices used earlier by Tatoglu et al. (2016). Relying on five-point scale items (1="never used" to $5=$ "used very extensively"), the relative use of HRM practices was measured by asking respondents to assess the level of use of various HRM practices ranging from training and development to recruitment and selection and performance appraisal.

The relative use of TM practices was measured through a total of $15 \mathrm{TM}$ practices developed by the CIPD. Again, using five-point scales (1="never used" to $5=$ "used very extensively") respondents were asked to identify the extent of use of each TM practice for career development of managers in their firms.

The extent of HRM-strategy alignment was assessed through a total of 7 items. Based on five-point scales ( $1=$ "not at all" to $5=$ "very much"), this construct was measured by asking respondents to identify to what extent HRM strategy endorses firm's business strategy and also to assess the relative importance of HRM department's role and involvement in serving firm's strategic priorities. These seven items are as follows: (1) HRM strategies are aligned to business need; (2) the HRM department supports the business strategy of the organisation; (3) the HRM department is at the forefront of shaping the strategic direction of the business; (4) the HRM department is considered a partner in the management of the business and an agent for change; (5) the HRM department is involved in the strategic planning process; (6) the HRM department is taken seriously by the senior management team of organisation; and (7) the HRM department is growing in importance.

Firm-specific effects were captured by the following two control variables which included subsidiary size and age. 
Subsidiary size was measured by five size categories determined by the number of employees, as shown in Table 1. An ordinal variable was created that takes the value from 1 to 5 to represent each category.

Subsidiary age was measured using the logarithm of the total number of years elapsed since the establishment of subsidiary.

\subsection{Common Method Bias}

Since all the data for independent and dependent variables of the study were collected from the same source, the items of the constructs were assessed for the existence of common method bias (CMB). We implemented the following design-related steps to reduce potential CMB. First, we pre-qualified the potential respondents to ensure that they have relevant knowledge of the research subject. Second, we informed all respondents that their responses were kept anonymous. Finally, we placed independent and dependent variables and constructs distant to each other and randomized items within each construct.

Moreover, CMB was tested through two separate statistical analyses. First, Harman's single factor test was used to see if most the variance can be explained by a single factor (Podsakoff and Organ, 1986). For this, we constrained the number of factors extracted in the EFA to be one rather than extracting through eigenvalues. Since the single factor result did not account for most the variance in the variables of the study, CMB is not an issue for the current study. To validate this result, common latent factor (CLF) test was also conducted. Firstly, two CFA models were constructed in such a way that in one of them all observed variables could load on their theoretical latent factors; while in the other they were also allowed to load to a single unmeasured latent common factor. These were compared to assess the presence of CMB (Podsakoff et al., 2003). When the CLF test was applied, this resulted in a slightly better model fit of the theoretical measurement model $\left(\chi^{2}=198.88, \mathrm{df}=113\right.$, $\mathrm{CFI}=0.95$, $)$ in comparison to the CLF model $\left(\chi^{2}=198.82, \mathrm{df}=112,\right)$. CMB was not a pervasive problem in the current study.

\subsection{Reliability and Validity of Measures}


In order to assess the psychometric properties of the constructs, first, EFA with principal component extraction and varimax rotation method was conducted. This initial stage was followed by the evaluation of the reliabilities of the scale items to determine the degree to which the scales of the study are free from error as well as internally consistent. In line with previous literature, the scale items which have less than 0.50 corrected item-total correlations and/or do not substantially contribute to the coefficient alpha of the construct were deleted (Netemeyer et al., 2003). The subsequent factor analyses revealed one-factor solutions except for HRM practices and TM practices constructs. The EFAs conducted for HRM practices and TM practices both produced four-factor solutions which are displayed in Tables 2 and 3, respectively.

The reliability of each scale was examined by computing their Cronbach's alpha coefficients. As shown in Table 4, the Cronbach's alpha values of the study's constructs ranged between 0.94 and 0.63 , exhibiting a satisfactory level of internal consistency (Hair et al., 2010).

\section{[Tables 2, 3, 4]}

\section{Analysis and Results}

The data analysis was undertaken in three main steps: First, an exploratory factor analysis (EFA) was conducted to extract the study's constructs; second, the measurement model for each construct was tested using confirmatory factor analysis (CFA) in order to determine if the extracted dimensions through EFA analysis offered a good fit to the data of the study; and finally, the relationships among the study's constructs as hypothesized in the conceptual framework were analysed through a structural equation modelling (SEM) procedure.

Table 5 shows the means, standard deviations, and correlations for the constructs of the model. The diagonal elements of the correlation matrix shown in Table 5 are the square root of the average variance extracted (AVE). In order to assess the discriminant validity of constructs, the square root of the AVE of each construct shown as the diagonal element of the matrix in Table 5 should be greater than all other entries in the corresponding row and 
column of which the diagonal element is a part (Fornell and Larcker, 1981). Our results meet this requirement, attesting a satisfactory level of discriminant validity of the constructs used in the model.

\section{[Table 5]}

Before testing the hypotheses of the study by means of SEM procedure, the psychometric properties of constructs in the hypothesized model were also evaluated by conducting a CFA of the item covariance matrix, using the maximum likelihood estimation procedure in AMOS. In this measurement model, each item's loading is restricted to its a priori factor and each factor is allowed to correlate with other factors. The main aim of CFA is to assess whether a given measurement model is valid and have the best fit among possible alternative measurement models. The hypothesised measurement model and the other two alternative models are shown in Table 6. Overall, the hypothesised measurement model provides the best fit with the data $\left(\chi^{2}=198.88, \mathrm{df}=113, \mathrm{CFI}=0.95, \mathrm{TLI}=0.94, \mathrm{RMSEA}=0.06\right.$, PCLOSE $=0.08)$ as compared to the other two alternative models.

\section{[Table 6]}

\subsection{Hypotheses Testing}

The structural relationships in the hypothesized model were tested using SEM in AMOS. In three subsequent steps the hypotheses of the study were examined through SEM analysis: first to test the general path relationships in the model, then to assess the mediation effect, and lastly to investigate the role of the moderator variable on the hypothesized relationships. Control variables included firm size and age.

\subsubsection{Analyses for testing path relationships}

Alternative models were tested to determine the optimal model based on the data. In the hypothesized model, TM practices have a mediation effect on the relationship between HRM practices and firm performance. As an alternative model, we examined the direct effects of 
both HRM practices and TM practices on firm performance. The comparisons of these structural models are shown in Table 7.

\section{[Table 7]}

According to the model comparisons, the mediation model has better fit values than the alternative model. Thus, the existence of the mediation effect is observed. In order to analyze the nature of the mediation effect of TM practices between HRM practices and firm

performance, the traditional casual steps approach advocated by Baron and Kenny (1986) was used. The aim of this analysis was to have a more accurate explanation for the chain of causation clarifying how or why an independent variable affects a dependent variable (Hair et al., 2010). After testing the existence and nature of the mediation effect of TM practices, the significance of this effect was assessed through the Sobel test: "an approximate significance test for the indirect effect of the independent variable on the dependent variable via the mediator" (Baron and Kenny, 1986:1177). The results are displayed in Table 8.

\section{[Table 8]}

The results validating the mediation effect of TM practices indicate that the effect of HRM practices on firm performance is fully contingent upon the mediation effect of TM practices, that is, HRM practices only become effective on firm performance through its effect on TM practices. Accordingly, the final structural model and the significant path relationships are shown in Figure 2.

[Figure 2]

Overall, the findings of the hypothesized model shown in Figure 2 and Table 9 indicate that firms' HRM practices are positively related to TM practices $(\gamma=0.65, \mathrm{p}<0.01)$, providing support for H1. In line with hypothesized path relationships, TM practices were positively 
associated with firm performance $(\gamma=0.37, \mathrm{p}<0.01)$, which corroborates $\mathrm{H} 2$. Finally, we also confirmed H3 that TM practices fully mediate the relationship between HRM practices and firm performance.

\section{[Table 9]}

\subsubsection{Analyses for testing moderation effect}

The hypothesized moderator effect of the construct HRM-strategy alignment was evaluated following the SEM methodology (Hair et al., 2010). First, existence of the measurement invariance across high and low groups of the moderator variable was validated. To do this, the sample was divided into two groups along with high vs. low of level of HRM-strategy alignment variable by a median split procedure. Then $\chi^{2}$ difference was checked to compare the model in which the hypothesized relationships were set to be equal across two groups with an unconstrained model in which the hypothesized paths varied freely across the low and high groups. The results of this analysis supported the existence of measurement model invariance across high and low HRM-strategy alignment groups $\left(\chi^{2}=8.204, \mathrm{df}=7, \mathrm{p}=0.35\right.$, $\mathrm{CFI}=0.96, \mathrm{TLI}=0.95$, RMSEA=0.04, PCLOSE=0.67) with fit indices being within acceptable levels and having an insignificant $\mathrm{p}$ value.

After validating measurement model invariance across two groups, moderation analysis was conducted in AMOS by testing the moderating effect of HRM-strategy alignment on the two hypothesized paths of the model of the study; first on HRM practices and TM practices, and then on TM practices and firm performance relationships to confirm hypotheses $\mathrm{H} 4$ and H5, respectively.

\section{[Table 10]}

The results of the moderation analyses shown in Table 10 suggest that HRM-strategy alignment moderates the relationship between HRM practices and TM practices in such a way that HRM practices have a stronger positive impact on TM practices for firms higher on 
HRM-strategy alignment as compared to those who are lower on HRM-strategy alignment. Thus, H4 was supported. Moreover, for those firms higher on HRM-strategy alignment, TM practices have a significant positive effect on firm performance whereas for the ones with lower HRM-strategy alignment this effect becomes insignificant. Therefore, H5 was also supported.

\section{Discussion and Conclusion}

RBV and dynamic capabilities were used to examine the link between HRM practices, TM practices and firm performance, and the moderating role of HRM and business strategy alignment within the context of an emerging market. Using SEM, the research confirmed that 1) A foundation of HRM practices that includes training and development, recruitment and selection, performance appraisal and workforce planning is positively related to $\mathrm{TM}$ practices; 2) TM that focuses on social capital building practices is positively related to firm performance; 3) TM that focuses on social capital building practices mediates the relationship between HRM practice and firm performance; 4) HRM strategy and business strategy alignment moderates the relationship between HRM practices and TM practices; and 5) HRM strategy and business strategy alignment moderates the relationship between TM practices and firm performance, such that the higher level of HRM-strategy alignment increases the positive effect of TM practices upon firm performance.

The contribution of this paper is threefold. First, the research is novel in that, until now, research examining the link between HRM practice, TM and firm performance in an emerging market context through a combination of RBV and dynamic capabilities has been absent in the literature. Second, by considering whether HRM as a function is central to the organisation, the research adds to our understanding of the extent to which HRM integration is required for the HRM-TM-performance link. Third, the research sheds some light on the type of TM practices that impact performance.

TM practices are more likely to exist where organisations have a developed set of HRM practices. This would suggest that TM practices do not exist in isolation and to create a more focused set of practices, organisations require a bedrock or a set of zero-order capabilities for 
further refinement. While each of the HRM practices formed a significant part of the bundle, training and development, recruitment and selection and performance appraisal were stronger contributors. These areas are particularly important to TM because these directly impact the nature and level of human capital within the organisation and help to manage workforce expectations. The need for flexibility within the TM system (Banks and Kepes, 2015, Minbaeva and Collings, 2013) would also suggest that a platform of HRM practices provides a safety net that sustains the required fluidity of the TM system as a whole. Those with HRM expertise are also more likely to perceive the need for a suite of TM practices.

Each of the TM practices were associated with firm performance, but those with the strongest relationship included special tasks to stimulate learning, project teams, networking, in-house development programmes, cross-disciplinary working, formal career plans, coaching and mentoring. The nature of these activities are dynamic, unpredictable, are focused on personal and team growth but are combined with an individual plan for the future, ensuring a sense of stability in the organisation. The extent to which these are central in predicting firm performance will depend upon the nature and stability of the institutional environment, however, these represent opportunity-enhancing practices that change capabilities and constantly reconfigure the network of actors and how they interact (Jiang et al., 2012, Kaše et al., 2009, Fainshmidt et al., 2016), thus sending signals to the employees about what the organisation values (Martin and Cerdin, 2014). Thus, consistent with Collins and Clark (2003), TM practices centred on network building effect firm performance. The design of TM practices and how these practices combine, represent a dynamic capability in keeping with the social complexity and causal ambiguity that is central to RBV (Collins and Clark, 2003, Lado and Wilson, 1994, Barney and Wright, 1998).

This discussion implies that the organisation has a specialist function that is central to ensuring the alignment between the HRM and TM architectures. It is logical to assume that the HRM function would play an important role in ensuring the functioning of TM as a transmission mechanism. That HRM strategy-business strategy alignment only moderates the relationship between HRM practice and TM practice, and the relationship between TM practice and firm performance is testament to the contested nature of the HRM function. 
HRM strategy-business strategy alignment is not a required condition for these interactions to occur, but the relationship between TM and performance is strengthened where HRM is considered central to the organisation. This may work in the following ways - HRM practice and TM practice might be better tailored to the needs of the business; HRM involvement at senior levels promotes a stronger culture where a range of interests are considered; strategic integration of the HRM function enables it to ensure brand consistency and alignment (Farndale et al., 2010). Some authors suggest that TM is too important to be left to HRM managers and that human-capital centric organisations rarely consider their HRM function as being central to a discussion of TM (Fernandez-Araoz et al., 2011, Linden and Teece, 2014) - our findings partially corroborate this view, in that a strategically integrated HRM function is not essential for the HRM-TM-performance link to work.

This paper has sought to explain the HRM-TM-performance link by incorporating RBV with dynamic capabilities and viewing TM as a mechanism through which social capital can be accrued through a range of network-configuring practices. HRM practices themselves are not the source of competitive advantage (Fu et al., 2015), they form a platform which shapes an interest in creating a more focused talent management architecture. This is the apparatus that forms the dynamic capability of the organisation - altering the resource base and promoting change (Augier and Teece, 2008, Linden and Teece, 2014). Within an emerging market context, dynamic capabilities have the opportunity to yield significant returns as markets and therefore practices may be less developed and firms less able and inclined to mimic (Fainshmidt et al., 2016). TM practices that reinforce social ties, promote cooperation and sharing through collaboration yield superior performance gains. Much will depend upon the culture and norms of the institution, and path dependence will play a crucial role in the choice of whether to deploy TM practice, and the motivational emphasises of these practices (Bowman and Hird, 2014). However, a range of TM practices that reconfigure networks and change the composition of these networks (Kaše et al., 2009) creates advantage through social complexity and therefore, causal ambiguity. 


\subsection{Implications for Practice}

Managers need to configure their HRM architecture through a bedrock of HRM practice that focus on training and development, recruitment and selection, performance and workforce planning. The latter implies that organisations need to be proactive in the consideration of their human capital. With a developmental focus, these practices pave the way for a set of more focused TM practices that seek to enhance the social capital within the workforce through a range of activities that promote network development and knowledge sharing. Such practices may not be confined to the focal organisation, but can extend to the organisation's value chain by creating opportunities for secondments, joint project teams, co-location. While $\mathrm{HRM}$ as a function may not be highly regarded or well-developed, managers need to be aware of the benefits of constructing an HRM team that has broader business interests and can formulate suitable functional strategies that help the organisation achieve its targets. An integrated HRM function will enable the organisation to leverage more performance gains via the HRM-TM-performance link and articulate a TM strategy that encompasses a variety of stakeholder TM structures across the organisation, thus helping to embed relationships and foster knowledge sharing and development.

\subsection{Limitations and Further Research}

Establishing the importance of TM to firm performance and how TM connects to HRM practices and HRM strategy and business alignment is an important contribution of this paper. However, this study suffers from the limitations of any study of TM viewed through a positivist lens, it does not examine the way in which TM practices are conceptualised, understood and experienced. The use of managerial perceptions of firm performance introduces biases and measurement error and further studies should deploy a range of hard and soft measures, involve multiple informants and deploy a longitudinal approach to avoid CMB problems. In addition, the TM variables in the study are aligned to the prescriptions of the CIPD and therefore Western notions of what should be considered TM. Further studies should unpack how the meaning of TM shapes practice within a given context and who is responsible for translating diverse culture-bound conceptualisations of TM into practice. 


\section{References}

Adler, P., \& Kwon, S. (2002). Social capital: Prospects for a new concept. Academy of Management Review, 27(1), 17-40.

Ait Razouk, A. (2011). High-performance work systems and performance of French smalland medium-sized enterprises: examining causal order. The International Journal of Human Resource Management, 22(2), 311-330.

Al Ariss, A., Cascio, W.F., \& Paauwe, J. (2014). Talent management: Current theories and future research directions. Journal of World Business, 49(2), 173-179.

Ambrosini, V., \& Bowman, C. (2009). What are dynamic capabilities and are they a useful construct in strategic management? International Journal of Management Reviews, 11(1), 29-49.

Anand, N., Gardner, H.K., \& Morris, T. (2007). Knowledge-based innovation: Emergence and embedding of new practice areas in management consulting firms. Academy of Management Journal, 50(2), 406-428.

Augier, M., \& Teece, D. (2008). Strategy as evolution with design: The foundations of dynamic capabilities and the role of managers in the economic system. Organization Studies, 29(8\&9), 1187-1208.

Banks, G., \& Kepes, S. (2015). The influence of internal HRM activity fit on the dynamics within the "black box". Human Resource Management Review, 25(4), 352-367.

Barney, J. (1991). Firm resources and sustained competitive advantage. Journal of Management, 17, 99-129.

Barney, J., \& Wright, P. (1998). On becoming a strategic partner: The role of human resources in gaining competitive advantage. Human Resource Management, 37(1), 3146.

Baron, R.M., \& Kenny, D.A. (1986). The moderator-mediator variable distinction in social psychological research: Conceptual, strategic, and statistical considerations. Journal of Personality and Social Psychology, 51(6), 1173-1182.

Batt, R. (2002). Managing customer services: Human resource practices, quit rates, and sales growth. Academy of Management Journal, 45(3), 587-597. 
Beechler, S., \& Woodward, I. (2009). The global "war for talent". Journal of International Management, 15, 273-285.

Björkman, I., \& Soderberg, A. (2006). The HR function in large-scale mergers and acquisitions: The case study of Nordea. Personnel Review, 35(6), 654-670.

Boselie, P., Dietz, G., \& Boon, C. (2005). Commonalities and contradictions in HRM and performance research. Human Resource Management Journal, 15(3), 67-94.

Boudreau, J., \& Ramstad, P. (2005). Talentship, talent segmentation and sustainability: A new HR decision science paradigm for a new strategy definition. Human Resource Management, 44(2), 129-136.

Bowen, D.E., \& Ostroff, C. (2004). Understanding HRM-firm performance linkages: The role of the "strength" of the HRM system. Academy of Management Review, 29(2), 203-221.

Bowman, C., \& Hird, M. (2014). A resource-based view of talent management. In P. Sparrow, H. Scullion \& I. Tarique (Eds.), Strategic Talent Management: Contemporary Issues in International Context (pp. 71-83). Cambridge: Cambridge University Press.

Caldwell, R. (2003). The changing roles of personnel managers: Old ambiguities and new uncertainties. Journal of Management Studies, 40(4).

Chadee, D., \& Raman, R. (2012). External knowledge and performance of offshore IT service providers in India: the mediating role of talent management. Asia Pacific Journal of Human Resources, 50(4), 459-482.

Chowhan, J. (2016). Unpacking the black box: Understanding the relationship between strategy, HRM practices, innovation and organizational performance. Human Resource Management Journal, 26(2), 112-133.

Chuang, C.-H., Jackson, S.E., \& Jiang, Y. (2016). Can knowledge-intensive teamwork be managed? Examining the roles of HRM systems, leadership, and tacit knowledge. Journal of Management, 42(2), 524-554.

CIPD. (2012). Learning and Talent Development Annual Survey Report. CIPD: London. 
Collings, D., Demirbag, M., Mellahi, K., \& Tatoglu, E. (2010). Strategic orientation, human resource management practices and organizational outcomes: Evidence from Turkey. International Journal of Human Resource Management, 21(4): 2589-2613.

Collins, C.J., \& Clark, K.D. (2003). Strategic human resource practices, top management team social networks, and firm performance: The role of human resource practices in creating organizational competitive advantage. Academy of Management Journal, 46(6), 740-751.

Collins, C.J., \& Smith, K.G. (2006). Knowledge exchange and combination: The role of human resource practices in the performance of high-technology firms. Academy of Management Journal, 49(3), 544-560.

Connelly, B.L., Certo, S.T., Ireland, R.D., \& Reutzel, C.R. (2011). Signaling theory: A review and assessment. Journal of Management, 37(1), 39-67.

Cranfield University. (2003). CRANET Survey. Cranfield University.

Datta, D.K., Guthrie, J.P., \& Wright, P.M. (2005). Human resource management and labor productivity: does industry matter. Academy of Management Journal, 48(1), 135-145.

Demirbag, M., Collings, D.G., Tatoglu, E., Mellahi, K., \& Wood, G. (2014). Highperformance work systems and organizational performance in emerging economies: Evidence from MNEs in Turkey. Management International Review, 54(3), 325-359.

Demirbag, M., Tatoglu, E., \& Wilkinson, A. (2016). Adoption of high performance work systems by local subsidiaries of developed country and Turkish MNEs and indigenous firms in Turkey, Human Resource Management, 55(6), 1001-1024.

De Vos, A., \& Dries, N. (2013). Applying a talent management lens to career management: the role of human capital composition and continuity. International Journal of Human Resource Management, 24(9), 1816-1831.

Doh, J.P., Smith, R., Stumpf, S.A., \& Tymon Jr, W.G. (2014). Emerging markets and regional patterns in talent management: the challenge of India and China. In P. Sparrow, H. Scullion \& I. Tarique (Eds.), Strategic Talent Management: Contemporary Issues in International Context (pp. 224-253). Cambridge: Cambridge University Press. 
Dries, N. (2013). The psychology of talent management: A review and research agenda. Human Resource Management Review, 23(4), 272-285.

Fainshmidt, S., Pezeshkan, A., Frazier, M.L., Nair, A., \& Markowski, E. (2016). Dynamic capabilities and organizational performance: A meta-analytic evaluation and extension. Journal of Management Studies, 53(8), 1348-1380.

Farndale, E., Scullion, H., \& Sparrow, P. (2010). The role of the corporate HR function in global talent management. Journal of World Business, 45(2), 161-168.

Fernandez-Araoz, C., Groysberg, B., \& Nohria, N. (2011). How to hang on to your high potentials. Emerging best practices in managing your company's future leaders. Harvard Business Review, 10(October ), 76-83.

Florin, J., Lubatkin, M., \& Schulze, W. (2003). A social capital model of high-growth ventures. Academy of Management Journal, 46(3), 374-384.

Fornell, C., \& Larcker, D.F. (1981). Evaluating structural equation models with unobservable variables and measurement error. Journal of Marketing Research, 19(4), 39-50.

Foss, N.J., Pedersen, T., Fosgaard, M.R., \& Stea, D. (2015). Why complementary HRM practices impact performance: The case of rewards, job design, and work climate in a knowledge-sharing context. Human Resource Management, 54(6), 955-976.

Fu, N., Flood, P.C., Bosak, J., Rousseau, D.M., Morris, T., \& O'Regan, P. (2015). Highperformance work systems in professional service firms: Examining the practicesresources-uses-performance linkage. Human Resource Management, DOI: $10.1002 / \mathrm{hrm} .21767$, forthcoming.

Garavan, T.N. (2012). Global talent management in science-based firms: an exploratory investigation of the pharmaceutical industry during the global downturn. International Journal of Human Resource Management, 23(12), 2428-2449.

Gardner, H.K., Gino, F., \& Staats, B.R. (2012). Dynamically integrating knowledge in teams: Transforming resources into performance. Academy of Management Journal, 55(4), 998-1022.

Garrow, V.P., \& Hirsh, W.P. (2008). Talent management: Issues of focus and fit. Public Personnel Management, 37(4), 389-402. 
Glaister, K.W., \& Buckley, P.J. (1999). Performance relationships in UK international alliances. Management International Review, 39(2), 123-147.

Glaister, A.J., Liu, Y., Sahadev, S., \& Gomes, E. (2014). Externalizing, internalizing and fostering commitment: The case of born-global firms in emerging economies. Management International Review, 54(4), 473-496.

Gong, Y., Law, K.S., Chang, S., \& Xin, K.R. (2009). Human resources management and firm performance: The differential role of managerial affective and continuance commitment. Journal of Applied Psychology, 94(1), 263-275.

Gooderham, P.N., Morley, M.J., Parry, E., \& Stavrou, E. (2015). National and firm-level drivers of the devolution of HRM decision making to line managers. Journal of International Business Studies, 46(6), 715-723.

Groysberg, B. (2012). Chasing Stars: The Myth of Talent and the Portability of Performance: Princeton University Press.

Groysberg, B., McLean, A.N., \& Nohria, N. (2006). Are leaders portable? Harvard Business Review, 84(5), 92-100.

Guest, D.E., Michie, J., Conway, N., \& Sheehan, M. (2003). Human resource management and corporate performance in the UK. British Journal of Industrial Relations, 41(2), 291-314.

Guthridge, M., Komm, A., \& Lawson, E. (2008). Making talent a strategic priority. McKinsey Quarterly, 1, 49-59.

Hair, J.F., Black, W.C., Babin, B.J., \& Anderson, R.E. (2010). Multivariate Data Analysis A Global Perspective, 7th ed. Pearson Prentice Hall, New Jersey.

Harvey, W.S., \& Groutsis, D. (2015). Reputation and talent mobility in the Asia Pacific. Asia Pacific Journal of Human Resources, 53(1), 22-40.

Heffernan, M., Harney, B., Cafferkey, K., \& Dundon, T. (2016). Exploring the HRMperformance relationship: the role of creativity climate and strategy. Employee Relations, 38(3), 438-462. 
Helfat, C.E., Finkelstein, S., Mitchell, W., Peteraf, M., Singh, H., Teece, D., et al. (2009). Dynamic Capabilities: Understanding Strategic Change in Organizations. John Wiley \& Sons.

Helfat, C.E., \& Winter, S.G. (2011). Untangling dynamic and operational capabilities: Strategy for the (N) ever-changing world. Strategic Management Journal, 32(11), 1243-1250.

Hoque, K. (1999). Human resource management and performance in the UK hotel industry. British Journal of Industrial Relations, 37(3), 419-443.

Huang, J., \& Tansley, C. (2012). Sneaking through the minefield of talent management: The notion of rhetorical obfuscation. International Journal of Human Resource Management, 23(17), 3673-3691.

Huselid, M. (1995). The impact of human resource management on turnover, productivity and corporate financial performance. Academy of Managemet Journal, 38(3), 635-672.

Jiang, K., Lepak, D.P., Hu, J., \& Baer, J.C. (2012). How does human resource management influence organizational outcomes? A meta-analytic investigation of mediating mechanisms. Academy of Management Journal, 55(6), 1264-1294.

Jiang, K., Takeuchi, R., \& Lepak, D.P. (2013). Where do we go from here? New perspectives on the black box in strategic human resource management research. Journal of Management Studies, 50(8), 1448-1480.

Kang, S.C., \& Snell, S.A. (2009). Intellectual capital architectures and ambidextrous learning: a framework for human resource management. Journal of Management Studies, 46(1), 65-92.

Kaše, R., Paauwe, J., \& Zupan, N. (2009). HR practices, interpersonal relations, and intrafirm knowledge transfer in knowledge-intensive firms: a social network perspective. Human Resource Management, 48(4), 615-639.

Keller, J.R, \& Cappelli, P. (2014). A supply-chain approach to talent management. In P. Sparrow, H. Scullion \& I. Tarique (Eds.), Strategic Talent Management: Contemporary Issues in International Context (pp. 117-150). Cambridge: Cambridge University Press. 
Kim, Y., \& Ployhart, R.E. (2014). The effects of staffing and training on firm productivity and profit growth before, during, and after the Great Recession. Journal of Applied Psychology, 99(3), 361-389.

Lado, A., \& Wilson, M. (1994). Human resource systems and sustained competitive advantage: A competency-based perspective. Academy of Management Review, 19, 699-727.

Lawler, E., \& Boudreau, J. (2009). What makes HR a strategic partner? People \& Strategy, $32(1), 15-22$.

Lawler, E., \& Mohrman, S. (2003). HRM as a strategic partner: What does it take to make it happen. Human Resource Planning, 26, 15-29.

Lawler III, E. (2009). Make human capital a source of competitive advantage. Organizational Dynamics, 38(1), 1-7.

Lepak, D.P., Liao, H., Chung, Y., \& Harden, E.E. (2006). A conceptual review of human resource management systems in strategic human resource management research. Research in Personnel and Human Resources Management, 25(1), 217-271.

Lin, C.-H., Sanders, K., Sun, J.-M., Shipton, H., \& Mooi, E.A. (2016). From customeroriented strategy to organizational financial performance: The role of human resource management and customer-linking capability. British Journal of Management, 27(1), 21-37.

Linden, G., \& Teece, D. (2014). Managing expert talent. In P. Sparrow, H. Scullion \& I. Tarique (Eds.), Strategic Talent Management: Contemporary Issues in International Context (pp. 87-116). Cambridge: Cambridge University Press.

Lockett, A., Thompson, S., \& Morgenstern, U. (2009). The development of the resourcebased view of the firm: A critical appraisal. International Journal of Management Reviews, 11(1), 9-28.

Mäkelä, K., \& Brewster, C. (2009). Interunit interaction contexts, interpersonal social capital, and the differing levels of knowledge sharing. Human Resource Management, 48(4), 591-613. 
MacDuffie, J.P. (1995). Human resource bundles and manufacturing performance: Organizational logic and flexible production systems in the world auto industry. Industrial and Labor Relations Review, 48, 197-221

Martin, G., \& Cerdin, J.-L. (2014). Employer branding and career theory: New directions for research In P. Sparrow, H. Scullion \& I. Tarique (Eds.), Strategic Talent Management: Contemporary Issues in International Context. Cambridge: Cambridge University Press.

McMahan, G.C., Virick, M., \& Wright, P.M. (1999). Alternative theoretical perspectives for strategic human resource management revisited: Progress, problems, and prospects. In P. Wright, L. Dyer, J. Boudreau \& G. Milkovich (Eds.), Research in Personnel and Human Resource Management (pp. 99-122). Greenwich: Jai Press.

Mellahi, K., \& Collings, D.G. (2010). The barriers to effective global talent management: The example of corporate élites in MNEs. Journal of World Business, 45(2), 143-149.

Mellahi, K., Demirbag, M., Collings, D.C., Tatoglu, H. \& Hughes, M. (2013). Similarly different: a comparison of HRM practices in MNE subsidiaries and local firms in Turkey, International Journal of Human Resource Management, 24(12), 2339-2368.

Meyers, M.C., \& van Woerkom, M. (2014). The influence of underlying philosophies on talent management: Theory, implications for practice, and research agenda. Journal of World Business, 49(2), 192-203.

Michie, J., \& Sheehan, M. (2005). Business strategy, human resources, labour market flexibility and competitive advantage. International Journal of Human Resource Management, 16(3), 445-464.

Minbaeva, D., \& Collings, D.G. (2013). Seven myths of global talent management. International Journal of Human Resource Management, 24(9), 1762-1776.

Netemeyer, R.G., Bearden, W.O., \& Sharma, S. (2003). Scaling Procedures: Issues and Applications. Thousand Oaks: Sage Publications.

Nijs, S., Gallardo-Gallardo, E., Dries, N., \& Sels, L. (2014). A multidisciplinary review into the definition, operationalization, and measurement of talent. Journal of World Business, 49(2), 180-191. 
Ostroff, C., \& Bowen, D.E. (2016). Reflections on the 2014 decade award: Is there strength in the construct of HR system strenght? Academy of Management Review, 41(2), 196214.

Paauwe, J., Guest, D., \& Wright, P. (Eds.). (2013). HRM \& Performance: Achievement \& Challenges. New York: Wiley.

Pelster, B., Schwartz, J., Rizzo, D., Valenzuela, J., \& Van Der Vyer, B. (2013). The war to develop talent, Resetting Horizons-Human Capital Trends 2013: Deloitte Consulting.

Peña, I., \& Villasalero, M. (2010). Business strategy, human resource systems, and organizational performance in the Spanish banking industry. International Journal of Human Resource Management, 21(15), 2864-2888.

Peng, M.W., \& Luo, Y. (2000). Managerial ties and firm performance in a transition economy: The nature of a micro-macro link. Academy of Management Journal, 43(3), 486-501.

Podsakoff, P.M., \& Organ, D.W. (1986). Self-reports in organizational research: Problems and prospects. Journal of Management, 12(4), 531-544.

Podsakoff, P.M., MacKenzie, S.B., Lee, J.Y., \& Podsakoff, N.P. (2003). Common method biases in behavioral research: A critical review of the literature and recommended remedies. Applied Psychology, 88(5), 879-903.

Ramsay, H., Scholarios, D., \& Harley, B. (2000). Employees and high-performance work systems: Testing inside the black box. British Journal of Industrial Relations, 38(4), $501-531$.

Rindova, V.P., \& Kotha, S. (2001). Continuous "morphing": Competing through dynamic capabilities, form, and function. Academy of Management Journal, 44(6), 1263-1280.

Sahadev, S., \& Demirbag, M. (2011). Exploring variations in employment practices in the emerging economies of Europe: assessing the impact of foreign ownership and European integration, Human Resource Management Journal, 21(4), 395-414.

Schilke, O. (2014). Second-order dynamic capabilities: How do they matter? Academy of Management Perspectives, 28(4), 368-380. 
Schuler, R.S. (2015). The 5-C framework for managing talent. Organizational Dynamics, 44(1), 47-56.

Schuler, R.S., Jackson, S.E., \& Tarique, I. (2011). Global talent management and global talent challenges: Strategic opportunities for IHRM. Journal of World Business, 46(4), 506-516.

Shantz, A., Alfes, K., \& Arevshatian, L. (2016). HRM in healthcare: The role of work engagement. Personnel Review, 45(2), 274-295.

Sheehan, M. (2014). Human resource management and performance: Evidence from small and medium-sized firms. International Small Business Journal, 32(5), 545-570.

Sheehan, C., De Cieri, H., Cooper, B., \& Brooks, R. (2014). Exploring the power dimensions of the human resource function. Human Resource Management Journal, 24(2), 193210.

Snell, S.A., \& Dean, J.W. (1992). Integrated manufacturing and human resource management: A human capital perspective. Academy of Management Journal, 35(3), 467-504.

Snell, S.A., \& Youndt, M.A. (1995). Human resource management and firm performance: Testing a contingency model of executive controls. Journal of Management, 21(4), 711-737.

Soo, C., Tian, A.W., Teo, S.T., \& Cordery, J. (2016). Intellectual capital-enhancing HR, absorptive capacity, and innovation. Human Resource Management, DOI: $10.1002 / \mathrm{hrm} .21783$, forthcoming.

Sparrow, P., Hird, M., \& Balain, S. (2011). Talent Management: Time to Question the Tablets of Stone? Lancaster: Lancaster University Management School.

Sparrow, P., \& Makram, H. (2015). What is the value of talent management?: Building valuedriven processes within a talent management architecture. Human Resource Management Review, 25(3), 249-263.

Sparrow, P., Scullion, H., \& Tarique, I. (Eds.). (2014). Strategic Talent Management: Contemporary Issues in International Context. Cambridge: Cambridge University Press. 
Takeuchi, N. (2009). How Japanese manufacturing firms align their human resource policies with business strategies: testing a contingency performance prediction in a Japanese context. International Journal of Human Resource Management, 20(1), 34-56.

Takeuchi, R., Lepak, D.P., Wang, H.L., \& Takeuchi, K. (2007). An empirical examination of the mechanisms mediating between high-performance work systems and the performance of Japanese organizations. Journal of Applied Psychology, 92(4), 10691083.

Tansley, C., \& Tietze, S. (2013). Rites of passage through talent management progression stages: an identity work perspective. International Journal of Human Resource Management, 24(9), 1799-1815.

Tarique, I., \& Schuler, R. (2014). A typology of talent-management strategies. In P. Sparrow, H. Scullion \& I. Tarique (Eds.), Strategic Talent Management: Contemporary Issues in International Context (pp. 177-193). Cambridge: Cambridge University Press.

Tatoglu, E., Glaister, A.J., \& Demirbag, M. (2016). Talent management motives and practices in an emerging market: A comparison between MNEs and local firms. Journal of World Business, 51(2), 278-293.

Teece, D.J. (2014). The foundations of enterprise performance: Dynamic and ordinary capabilities in an (economic) theory of firms. Academy of Management Perspectives, 28(4), 328-352.

Thunnissen, M., Boselie, P., \& Fruytier, B. (2013). A review of talent management: 'Infancy or adolescence?'. International Journal of Human Resource Management, 24(9), 17441761.

Tsui, A.S., Pearce, J.L., Porter, L.W., \& Tripoli, A.M. (1997). Alternative approaches to the employee-organization relationship: Does investment in employees pay off? Academy of management Journal, 40(5), 1089-1121.

Vaiman, V., \& Holden, N. (2011). Talent management in Central and Eastern Europe. In H. Scullion \& D. Collings (Eds.), Global Talent Management (pp. 178-194). Abingdon: Taylor and Francis. 
Wall, T.D., Michie, J., Patterson, M., Wood, S.J., Sheehan, M., Clegg, C.W., et al. (2004). On the validity of subjective measures of company financial performance. Personnel Psychology, 57(1), 95-118.

Weerawardena, J., Mort, G.S., Liesch, P.W., \& Knight, G. (2007). Conceptualizing accelerated internationalization in the born global firm: A dynamic capabilities perspective. Journal of World Business, 42(3), 294-306.

Welbourne, T.M., \& Andrews, A.O. (1996). Predicting the performance of initial public offerings: should human resource management be in the equation? Academy of management Journal, 39(4), 891-919.

Whitener, E.M. (1990). Confusion of confidence intervals and credibility intervals in metaanalysis. Journal of Applied Psychology, 75, 315-321.

Winter, S.G. (2003). Understanding dynamic capabilities. Strategic Management Journal, 24(10), 991-995.

Wright, P.M., Gardner, T.M., \& Moynihan, L.M. (2003). The impact of HR practices on the performance of business units. Human Resource Management Journal, 13(3), 21-36.

Wright, P.M., Gardner, T.M., Moynihan, L.M., \& Allen, M.R. (2005). The relationship between HR practices and firm performance: Examining causal order. Personnel Psychology, 58(2), 409-446.

Youndt, M.A., \& Snell, S.A. (2004). Human resource configurations, intellectual capital, and organizational performance. Journal of Managerial Issues, 16(3), 337-360.

Youndt, M. A., Snell, S. A., Dean, J. W., \& Lepak, D. P. (1996). Human resource management, manufacturing strategy, and firm performance. Academy of management Journal, 39(4), 836-866. 
Table 1. Characteristics of respondent firms

\begin{tabular}{|c|c|c|c|}
\hline Characteristics & & Number & $\%$ \\
\hline \multirow[t]{2}{*}{ Respondent position } & $\begin{array}{l}\text { Upper level (e.g., Chairman/CEO, board member } \\
\text { and deputy general manager) }\end{array}$ & 82 & 41.4 \\
\hline & Medium level (department head and director) & 116 & 58.6 \\
\hline \multirow[t]{3}{*}{ Functional area } & General management & 69 & 34.9 \\
\hline & HRM & 114 & 57.5 \\
\hline & Administration & 15 & 7.6 \\
\hline \multirow[t]{11}{*}{ Industry sector } & Industrial, automotive and electrical equipment & 23 & 11.6 \\
\hline & Textile and apparel & 22 & 11.1 \\
\hline & Food, beverage and paper & 16 & 8.1 \\
\hline & Metal, wood, leather and glass & 18 & 9.1 \\
\hline & Chemical and pharmaceuticals & 10 & 5.1 \\
\hline & Other manufacturing & 19 & 9.6 \\
\hline & Wholesale and retail trade & 20 & 10.1 \\
\hline & Computer and engineering services & 11 & 5.6 \\
\hline & Financial services and consultancy & 21 & 10.6 \\
\hline & Hospitality and leisure services & 14 & 7.0 \\
\hline & Other services & 24 & 12.1 \\
\hline \multirow[t]{5}{*}{ Number of employees } & Less than 250 & 73 & 36.9 \\
\hline & $251-500$ & 40 & 20.2 \\
\hline & $501-1000$ & 33 & 16.7 \\
\hline & $1001-5000$ & 36 & 18.2 \\
\hline & More than 5000 & 16 & 8.0 \\
\hline Years of operation & Mean & \multicolumn{2}{|c|}{28.97} \\
\hline & $N$ & \multicolumn{2}{|c|}{198} \\
\hline
\end{tabular}


Table 2. Factor Analysis of HRM Practices

\begin{tabular}{|c|c|c|c|c|}
\hline Factors & $\begin{array}{l}\text { Factor } \\
\text { loads }\end{array}$ & $\begin{array}{l}\text { \% Variance } \\
\text { explained }\end{array}$ & $\begin{array}{l}\text { Cumulative } \\
\text { per cent }\end{array}$ & $\begin{array}{l}\text { Cronbach's } \\
\text { alpha }\end{array}$ \\
\hline Factor 1: Training \& development & & 23.63 & 23.63 & 0.85 \\
\hline $\begin{array}{l}\text { Training needs analysis to understand } \\
\text { future skill needs of the business }\end{array}$ & 0.84 & & & \\
\hline Career planning & 0.80 & & & \\
\hline $\begin{array}{l}\text { Skills audit to understand the current } \\
\text { skills base of the business }\end{array}$ & 0.73 & & & \\
\hline Factor 2: Recruitment \& selection & & 21.62 & 45.25 & 0.82 \\
\hline Risk management & 0.83 & & & \\
\hline Role design & 0.77 & & & \\
\hline Job analysis & 0.73 & & & \\
\hline Factor 3: Workforce planning & & 18.09 & 63.34 & 0.88 \\
\hline Demand forecasting & 0.90 & & & \\
\hline Supply forecasting & 0.86 & & & \\
\hline Factor 4: Performance appraisal & & 17.56 & 80.90 & 0.83 \\
\hline Personality or attitude tests & 0.89 & & & \\
\hline Performance or competency tests & 0.82 & & & \\
\hline
\end{tabular}

K-M-O Measure of Sampling Adequacy=0.85; Barlett Test of Sphericity=1098.76; $<<0.000$.

Table 3. Factor Analysis of TM Practices

\begin{tabular}{lcccc}
\hline Factors & $\begin{array}{c}\text { Factor } \\
\text { loads }\end{array}$ & $\begin{array}{c}\text { Variance } \\
\text { explained }\end{array}$ & $\begin{array}{c}\text { Cumulative } \\
\text { per cent }\end{array}$ & $\begin{array}{c}\text { Cronbach's } \\
\text { alpha }\end{array}$ \\
\hline Factor 1: Work-based systems & & 30.49 & 30.49 & 0.92 \\
Special tasks to stimulate learning & 0.83 & & & \\
Project teams & 0.82 & & & \\
Networking & 0.80 & & & \\
In-house development programmes & 0.76 & & & \\
Cross disciplinary project working & 0.75 & & & \\
Instructor-led off the job training & 0.74 & & \multirow{2}{*}{50.51} & \\
Formal career plans & 0.61 & & & \\
Factor 2: International assignments & & 20.02 & \\
Short term international assignments & 0.87 & & & \\
Training in international operations & 0.86 & & & \\
International project teams & 0.85 & & & \\
Factor 3: Career portfolio building & & 14.69 & 65.20 &
\end{tabular}


Internal secondment $\quad 0.82$

External secondment $\quad 0.71$

Job rotation 0.69

$\begin{array}{llll}\text { Factor 4: HRM-led systems } & 12.55 & 77.75 & 0.91\end{array}$

Coaching $\quad 0.82$

Mentoring 0.79

K-M-O Measure of Sampling Adequacy=0.90; Barlett Test of Sphericity=2403.62; $<<0.000$.

Table 4. Internal Consistency of Constructs

\begin{tabular}{lcc}
\hline Construct & Number of items & Cronbach's alpha \\
\hline Firm performance & 2 & 0.63 \\
HRM practices & 10 & 0.89 \\
TM practices & 15 & 0.94 \\
HRM-strategy alignment & 7 & 0.91 \\
\hline
\end{tabular}

Table 5. Descriptive Statistics and Correlations among Constructs ${ }^{\mathrm{a}}$

\begin{tabular}{lcccccccc}
\hline Construct & Mean & SD $^{\mathbf{b}}$ & $\mathbf{1}$ & $\mathbf{2}$ & $\mathbf{3}$ & $\mathbf{4}$ & $\mathbf{5}$ & $\mathbf{6}$ \\
\hline 1. Firm performance & 3.78 & 0.69 & 0.69 & & & & & \\
2. HRM practices & 3.66 & 0.75 & $0.23^{*}$ & 0.72 & & & & \\
3. TM practices & 2.88 & 0.90 & $0.26^{*}$ & $0.56^{*}$ & 0.75 & & & \\
4. HRM-strategy alignment & 3.89 & 0.79 & 0.12 & $0.49^{*}$ & $0.29^{*}$ & 0.77 & & \\
5. Firm age & 28.9 & 29.9 & 0.08 & 0.01 & 0.06 & -0.01 & - & \\
6. Firm size & 2.38 & 1.36 & 0.21 & 0.12 & 0.21 & $0.27^{*}$ & $0.23^{*}$ & - \\
\hline
\end{tabular}

\section{Notes:}

${ }^{a}$ Italicized values on the diagonal are the square root of the AVE values.

${ }^{\mathrm{b}} \mathrm{S} . \mathrm{D} .=$ standard deviation.

$* \mathrm{p}<0.01$.

Table 6. Results of Confirmatory Factor Analysis for Study Constructs

\begin{tabular}{|c|c|c|c|c|c|c|c|c|c|}
\hline \multirow[b]{2}{*}{ Model } & \multicolumn{5}{|c|}{ Model fit indices } & \multicolumn{4}{|c|}{ Model differences } \\
\hline & $\chi^{2}$ & df & CFI & TLI & RMSEA & $\chi^{2}$ & $\Delta \mathbf{d f}$ & $\mathbf{p}$ & Details \\
\hline $\begin{array}{l}\text { 1. Hypothesized 4-factor model: } \\
\text { HRM practices, TM practices, HRM-strategy } \\
\text { alignment and firm performance. }\end{array}$ & 198.8 & 113 & 0.95 & 0.94 & 0.06 & & & & \\
\hline $\begin{array}{l}\text { 2. Alternative 3-factor model: } \\
\text { HRM practices and TM practices are } \\
\text { combined as one factor, HRM-strategy } \\
\text { alignment and firm performance. }\end{array}$ & 315.2 & 116 & 0.88 & 0.86 & 0.09 & 116.4 & 3 & 0.001 & Model 2 to 1 \\
\hline $\begin{array}{l}\text { 3. Alternative 2-factor model: } \\
\text { HRM practices, } T M \text { practices, } H R M \text { - } \\
\text { strategy alignment are combined as one } \\
\text { factor and firm nerformance. }\end{array}$ & 680.6 & 118 & 0.66 & 0.61 & 0.16 & 481.8 & 5 & 0.001 & Model 3 to 1 \\
\hline
\end{tabular}


Table 7. Model Comparisons for Structural Models

\begin{tabular}{lccccc}
\hline \multirow{2}{*}{ Model } & \multicolumn{5}{c}{ Model fit indices } \\
\cline { 2 - 6 } & $\chi^{2}$ & df & CFI & TLI & RMSEA \\
\hline $\begin{array}{l}\text { Mediation model: } \\
\text { TM practices mediate the relationship between }\end{array}$ & 58.8 & 33 & 0.96 & 0.95 & 0.06 \\
$\begin{array}{l}\text { HRM practices and firm performance. } \\
\text { Alternative model: }\end{array}$ & & & & & \\
$\begin{array}{l}\text { HRM practices and TM practices have direct } \\
\text { effects on firm performance. }\end{array}$ & 125.4 & 33 & 0.86 & 0.82 & 0.12 \\
\hline
\end{tabular}

Table 8. Mediation Effect

\begin{tabular}{lc}
\hline & Standardized parameter estimate \\
\hline HRM practices $\rightarrow$ Firm performance & $0.32 * *$ \\
HRM practices $\rightarrow$ TM practices & $0.65^{* *}$ \\
TM practices $\rightarrow$ Firm performance & $0.30 *$ \\
HRM practices $\rightarrow$ (TM practices $) \rightarrow$ Firm performance & 0.11 \\
\hline
\end{tabular}

Sobel test for: HRM practices $\rightarrow$ TM practices $\rightarrow$ Firm performance $\left(1.93^{*}\right)$.

$* \mathrm{p}<0.05 ; * \mathrm{*}<0.01$.

Table 9. Parameter Estimates

\begin{tabular}{lccc}
\hline Hypothesized Path & $\begin{array}{c}\text { Non-standardized } \\
\text { parameter estimate }\end{array}$ & $\begin{array}{c}\text { Standardized } \\
\text { parameter estimate }\end{array}$ & t value \\
\hline H1: HRM practices $\rightarrow$ TM practices & 0.78 & 0.65 & $7.38^{*}$ \\
H2: TM practices $\rightarrow$ Firm performance & 0.18 & 0.37 & $2.81^{*}$ \\
\hline
\end{tabular}
*p<0.01.

Table 10. Moderation Effect

Hypothesized path Hypothesized path

HRM practices $\rightarrow$ TM practices (H4) $\quad$ TM practices $\rightarrow$ Firm performance (H5) 
High alignment

Low alignment

${ }^{*} \mathrm{p}<0.01$.
$0.83 *$

$0.21 *$
$0.76^{*}$

0.14

\section{Figure 1. Conceptual Framework}

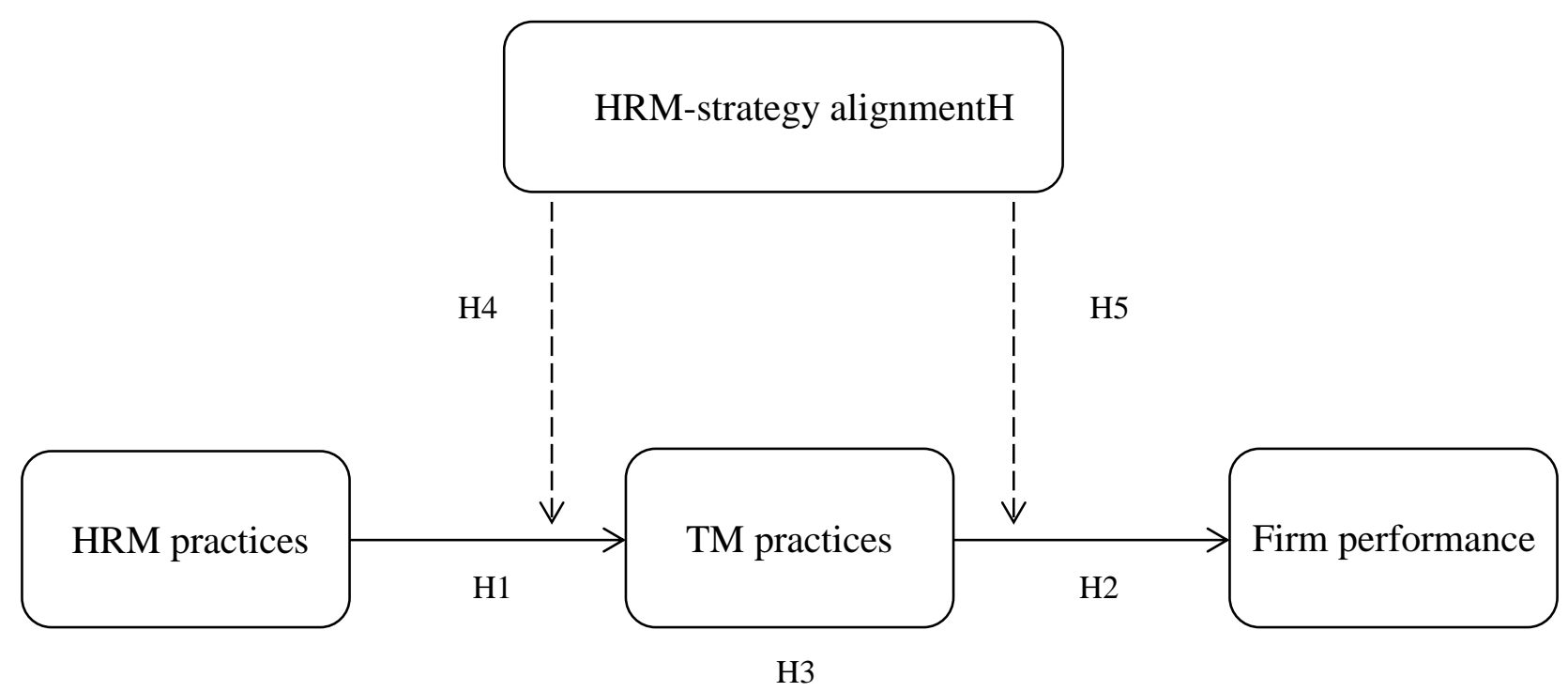


Figure 2. Results of SEM Model

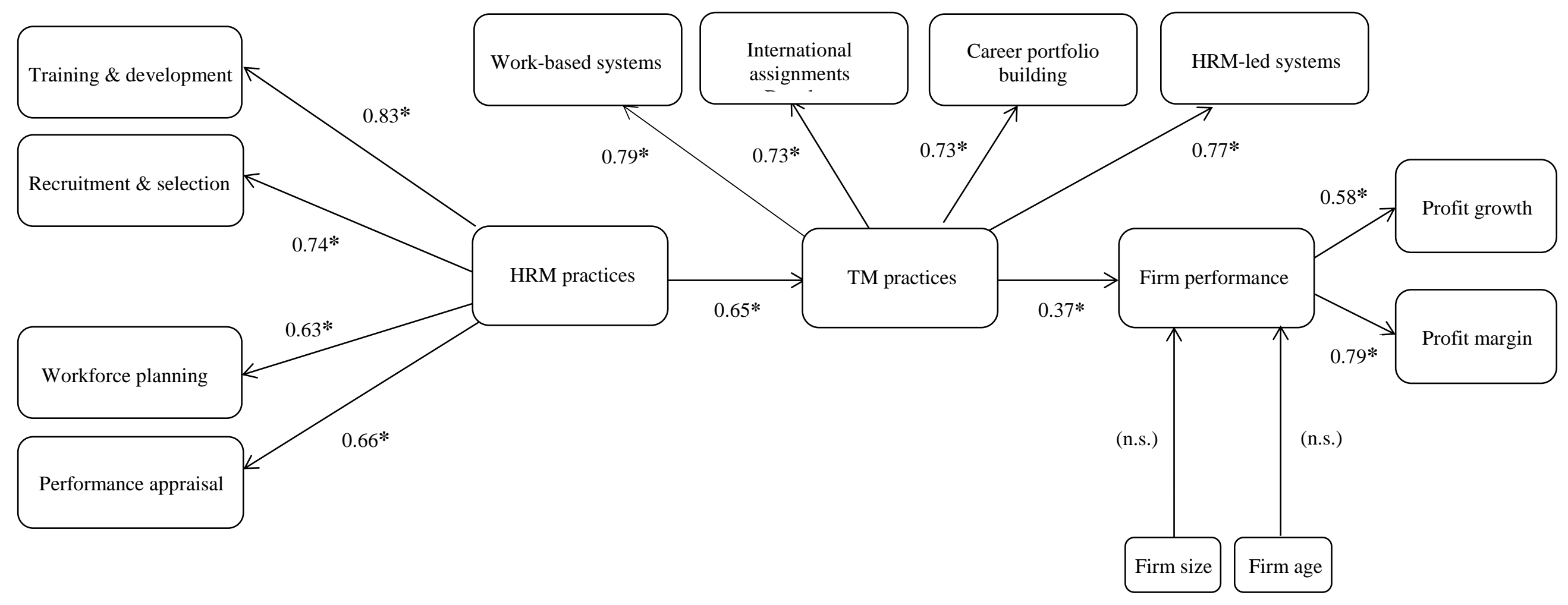

